\section{Effects of Irrigation Frequency and Nitrogen Fertilizer Rate on Water Stress, Nitrogen Uptake, and Plant Growth of Container-grown Rhododendron}

\author{
Carolyn F. Scagel ${ }^{1}$ \\ U.S. Department of Agriculture, Agricultural Research Service, Horticultural \\ Crops Research Unit, 3420 NW Orchard Avenue, Corvallis, OR 97330
}

\section{Guihong Bi}

Truck Crops Branch Experiment Station, Mississippi State University, 2024

Experiment Station Road, Crystal Springs, MS 39059

\author{
Leslie H. Fuchigami and Richard P. Regan \\ Department of Horticulture, Oregon State University, Corvallis, OR 97330
}

Additional index words. nitrogen uptake, water use, Rhododendron 'P.J.M. Compact', Rhododendron 'English Roseum', Rhododendron 'Gibraltar', nursery production

\begin{abstract}
The influence of irrigation frequency (same amount of water per day given at different times) and nitrogen $(N)$ fertilizer rate on water stress [stomatal conductance $\left(g_{\mathrm{S}}\right)$ ], $\mathbf{N}$ uptake, and growth (biomass) of container-grown evergreen Rhododendron 'P.J.M. Compact' and 'English Roseum' and deciduous Rhododendron 'Gibraltar' was evaluated. Both $\mathbf{N}$ deficiency and high $\mathbf{N}$ rate increased water stress. Water stress was greatest in plants fertilized with the highest $N$ rate and $g_{S}$ of plants grown with the higher $N$ rates changed more in response to water deficits resulting from irrigation treatments and seasonal climatic changes. Watering plants more frequently decreased water stress of plants fertilized with higher $\mathbf{N}$ rates and altering irrigation frequency had little impact on alleviating water stress of $\mathbf{N}$-deficient plants. Increasing irrigation frequency decreased $\mathrm{N}$ uptake efficiency ( $\mathrm{N}$ uptake per gram $\mathrm{N}$ applied), increased $\mathrm{N}$ use efficiency (growth per gram $\mathbf{N}$ uptake) and altered biomass allocation with little influence on total plant biomass. Response of biomass allocation to $\mathrm{N}$ rates was similar among cultivars and response of biomass allocation to irrigation frequency varied among cultivars. Altering irrigation frequency changed either the availability of $N$ in the growing substrate or the ability of roots to absorb $\mathrm{N}$. Our results indicate that transitory increases in plant water stress can alter $\mathbf{N}$ uptake, $\mathbf{N}$ use, and plant form without detectable changes in total plant biomass.
\end{abstract}

The production of high-quality containergrown nursery plants requires adequate nutrients and water during production. Negative growth responses to excess $\mathrm{N}$ can occur from increased salinity, disruption of the balance between $\mathrm{N}$ and other nutrients, or increased water stress (Cabrera, 2004). Fertilizer application rates commonly used for container-grown

Received for publication 27 July 2011. Accepted for publication 4 Oct. 2011.

This work was funded, in part, by the USDAARS-Northwest Center for Nursery Crop Research, the Oregon State University Agricultural Research Foundation, and the American Rhododendron Society. We gratefully acknowledge Jesse Mitchell, Suean Ott, Lisa Tribbet, and Rose Jepson for technical assistance and Monrovia Nursery, Dayton, OR, for plant materials.

Mention of trade names or commercial products in this publication is solely for the purpose of providing specific information and does not imply recommendation or endorsement by the U.S. Department of Agriculture.

${ }^{1}$ To whom reprint requests should be addressed; e-mail Carolyn.Scagel@ars.usda.gov. crops are based on optimal water availability, a condition that rarely exists in commercial production systems. Fertilizer management effects on plant water use and drought stress during production for many crops has not been evaluated fully (Linder et al., 1987; Tan and Hogan, 1997). With some woody perennial plants it is possible that growth can be enhanced more by minimizing water stress than by increasing fertility (Rose et al., 1999).

The soilless substrate used during container production of nursery plants has a low nutrient and water-holding capacity and large irrigation quantities can result in nutrient losses from the container. Maintaining plant-available water near $100 \%$ field capacity in the growing substrate is believed to maximize plant growth (Beeson, 1992); however, this objective is impracticable in commercial practice. Reduced irrigation volume in combination with increased irrigation frequency can be used to decrease runoff of nutrients and water in nurseries (Fare et al., 1994). Increasing irrigation frequency can increase growth of containergrown plants or have no influence on growth (Beeson, 1992; Fare et al., 1994; Keever and Cobb, 1985). The growth responses of container-grown plants using deficit irrigation regimes have been investigated and acceptable growth was measured when the growing substrate was allowed to dry to $40 \%$ to $75 \%$ of container capacity before irrigation (Beeson, 2006; Welsh and Zajicek, 1993). Cumulative actual evapotranspiration was similar between control plants grown at $100 \%$ container capacity and plants grown at $40 \%$ container capacity (Beeson, 2006), suggesting this range of water stress has little influence on photosynthesis and carbon gain.

Nutrient uptake is a function of nutrient availability in the rhizosphere solution. Transpiration can cause large differences between the water content in the rhizosphere and that in the bulk growing substrate. Changes of a few percent in water content of a growing substrate can induce 4- to 5-fold decreases in the hydraulic conductivity of the substrate and can potentially limit nutrient acquisition by plants (Raviv et al., 1999). Increasing irrigation frequency may increase availability of nutrients and nutrient uptake efficiency and decrease the amount of fertilizer required for optimal growth. Several researchers suggest increasing irrigation frequency could compensate for certain nutrient deficiencies, and lower yields of plants irrigated less frequently may be a result of nutrient shortage rather than water shortage (Buljovcic and Engels, 2001; Silber et al., 2003; Xu et al., 2004).

Recently, we described the influence of $\mathrm{N}$ availability on growth and uptake and storage of $\mathrm{N}$ and other nutrients by container-grown evergreen and deciduous cultivars of Rhododendron spp. (Bi et al., 2007a; Scagel et al., 2007, 2008) and observed an apparent increase in water use with increasing rate of $\mathrm{N}$ fertilizer application. Improved knowledge of the combined influence of irrigation and nutrient management during nursery production of container-grown plants is needed to develop integrated nursery production practices that optimize nutrient and water use. The objective of this study was to investigate the influence of water stress (as induced by irrigation frequency) on growth and $\mathrm{N}$ uptake of one deciduous and two evergreen cultivars of Rhododendron grown with different rates of $\mathrm{N}$ fertilizer in containers.

\section{Materials and Methods}

Plant culture. Plants used in this experiment were two evergreen cultivars of Rhododendron, Rhododendron 'P.J.M. Compact', ARS\#874 (PJM), and Rhododendron 'English Roseum', RHS\#58 (ER), and one deciduous cultivar, Rhododendron 'Gibraltar', RHS\#58 (AZ), obtained from a commercial nursery as 1 -year-old liner $\left(112-\mathrm{cm}^{3}\right.$ rooting volume) stock of clonally propagated tissue-cultured plants. Plants were transplanted on $25 \mathrm{Apr}$. 2005 into 3.8-L (1-gal.) containers (GL-400; Nursery Supplies, Inc., McMinnville, OR) filled with a substrate of bark, sphagnum peatmoss, perlite, vermiculite, dolomitic lime, and gypsum (SB-300; Sun Gro Horticulture, Bellevue, WA) 
and were grown outdoors in Corvallis, OR (lat. $45^{\circ} 59^{\prime} 04^{\prime \prime} \mathrm{N}$, long. $123^{\circ} 27^{\prime} 22^{\prime \prime} \mathrm{W}$ ).

Nitrogen treatments. Twenty plants of each cultivar were randomly assigned to one of four groups and fertilized twice a week from 29 Apr. 2005 to 2 Sept. 2005 (N05 rate). During each fertilizer application, one group received $250 \mathrm{~mL}$ of $\mathrm{N}$-free fertilizer (1.06 mg. $\mathrm{mL}^{-1}$, Cornell No N Eq. 0-6-27; Greencare Fertilizers, Kankakee, IL) and plants in the other groups received $250 \mathrm{~mL}$ of the $\mathrm{N}$ free fertilizer plus $35 \mathrm{mg} \cdot \mathrm{L}^{-1}, 70 \mathrm{mg} \cdot \mathrm{L}^{-1}$, or 140 $\mathrm{mg} \cdot \mathrm{L}^{-1} \mathrm{~N}\left(\mathrm{NH}_{4} \mathrm{NO}_{3}\right.$; Sigma Aldrich, St. Louis, $\mathrm{MO}$ ). The $\mathrm{N}$ concentration in irrigation water was measured periodically from May to Oct. 2005 using ion selective electrodes (Thermo Electron Corp., Waltham, MA). Concentrations of nitrate and ammonium in irrigation water were less than $28 \mathrm{mg} \cdot \mathrm{L}^{-1} \mathrm{NO}_{3}$ and $10 \mathrm{mg} \cdot \mathrm{L}^{-1}$ $\mathrm{NH}_{4}$, respectively. The $\mathrm{N}$ supplied from irrigation water was accounted for in calculating the total amount of $\mathrm{N}$ applied to plants.

Irrigation treatments. Plants in each N05 rate were randomly assigned to one of two groups and irrigated daily at two different frequencies (W05 treatment) by drip irrigation from 2 May 2005 to 30 Sept. 2005 using one drip emitter $\left(2 \mathrm{~L} \cdot \mathrm{h}^{-1}\right.$ flow rate; Netafim Co., Valley Stream, NY) per container. Plants in one group were irrigated to $100 \%$ container capacity at 0800 HR every morning (W100) and plants in the second group received the same amount of water each day as plants in the W100 treatment but in equal volume split applications at $0800 \mathrm{HR}$ and $1430 \mathrm{HR}$ (W50). The irrigation volumes were corrected weekly based on gravimetric determination of the average container capacity measured in three reference plants for each cultivar grown with the highest N05 rate in both irrigation treatments. Climate data were obtained for the duration of the experiment from a U.S. Bureau of Reclamation AgriMet weather station (CRVO) located $5 \mathrm{~km}$ from the experimental site. Before irrigation, treatments were started pans were placed below each container to collect runoff from containers. After each irrigation event, any water in pans beneath containers was added back into containers. This procedure was seldom necessary in W100 plants and never necessary in W50 plants.

Harvests. Ten plants of each cultivar were harvested in Apr. 2005 for initial estimates of biomass and nutrient composition, and in Nov. 2005, five plants of each cultivar from each N05 rate and W05 treatment combination were harvested. Shoots were cut at the soil surface, separated into leaves and stems, and divided into 1-year-old and 2-year-old structures, when applicable. Roots were removed from containers and washed from the substrate. Leaves, stems, and roots were dried at $65{ }^{\circ} \mathrm{C}$ in a forced-air oven, weighed, ground to pass through a 40-mesh screen, and analyzed for nutrient composition.

Stomatal conductance measurements. A steady-state porometer (LI-1600; LI-COR, Lincoln, NE) was used to measure water loss from transpiring leaves. All leaves were completely dry before any readings were taken. A leaf sensor head exposing $1 \mathrm{~cm}^{2}$ of leaf area to a dry air stream was used and leaf temperature, cuvette temperature, and cuvette relative humidity were recorded. Leaf transpiration rate $\left(\mathrm{mmol} \cdot \mathrm{m}^{-2} \cdot \mathrm{s}^{-1}\right)$ was determined from the volumetric flow rate. Stomatal conductance was calculated using the measured values of relative humidity, leaf and air temperature, and flow rate (Cowan, 1977; LI-COR, 1989). Measurements were taken at midday (between $1100 \mathrm{HR}$ and $1300 \mathrm{HR}$ ) and in late afternoon (between $1500 \mathrm{HR}$ and $1700 \mathrm{HR}$ ) on the same leaves from five plants of each cultivar in each N05 rate and W05 treatment nine times between 17 July 2005 and 22 Oct. 2005. The same plants were used for measurements at each date and sampling was randomized between treatments within each cultivar during measurement periods.

Nitrogen analyses and calculations. Samples taken for nutrient analyses were analyzed for concentrations of $\mathrm{N}$ by combustion (Tru Spec CHN; LECO Corp., St. Joseph, MI) (Bi et al., 2007b). Samples of the growing substrate were taken at the beginning of the experiment and analyzed for nutrient composition by standard methods (Berg and Gardner, 1979). Total biomass was calculated as the sum of dry weights overall structures and biomass allocation between different structures was calculated as the proportion (\%) of total biomass in different structures. The $\mathrm{N}$ content of each plant structure was calculated by multiplying the $\mathrm{N}$ concentration $\left(\mathrm{mg} \cdot \mathrm{g}^{-1}\right)$ in samples of each structure by the dry weight of each structure. Total plant content $(\mathrm{mg})$ of $\mathrm{N}$ was calculated as the sum overall structures. Net biomass growth and net nutrient uptake between May 2005 and Nov. 2005 (2005 growth and 2005 uptake) were estimated by subtracting the average biomass or nutrient content of each cultivar in May 2005 from the biomass or nutrient content of individual plants harvested in Nov. 2005.

Statistical analyses. Containers were arranged in a randomized design with each treatment unit (container) replicated five times for each $\mathrm{N} 05$ rate $\left(0,35,70,140 \mathrm{mg} \cdot \mathrm{L}^{-1}\right.$ $\mathrm{N}$ ), irrigation treatment (W100, W50), and cultivar (ER, PJM, AZ). All statistical analyses were performed using Statistica ${ }^{\circledR}$ (Statsoft, Inc., Tulsa, OK). Data were tested for homogeneity of variance using Levene's test and normality (Kolmogorov-Smirnov test). Allocation ( $\%$ of total) data were arcsinetransformed before analyses and backtransformed means are presented. Data were analyzed using a combination of analysis of variance (ANOVA) and regression techniques as described subsequently. When appropriate based on ANOVA results, means for significant effects and their interactions were compared using Tukey's honestly significant difference test at $P<0.05$ (THSD $_{0.05}$ ) or polynomial contrasts based on N05 rate. Coefficients from regression models were compared using Z-tests (Paternoster et al., 1998).

The influence of N05 rate and W05 treatment on $g_{\mathrm{S}}$ was assessed separately at each measurement date using ANOVA in a full factorial design with cultivar, N05 rate, and W05 treatment as between-subject main effects and time of day (midday and late afternoon) as a within-subject repeated measure.

The influence of N05 rate and W05 treatment on biomass, $\mathrm{N}$ content, and biomass allocation was assessed using ANOVA in a full factorial design with cultivar, N05 rate, and W05 treatment as main effects. The influence of irrigation frequency on relationships between N05 rate and $\mathrm{N}$ uptake ( $\mathrm{N}$ uptake efficiency) and $\mathrm{N}$ uptake and growth ( $\mathrm{N}$ use efficiency) were assessed using best subsets regression. Mallow's Cp was the criterion for choosing the best subset of predictor effects from linear and quadratic models. Intercepts and regression coefficients for relationships were calculated for each cultivar and W05 treatment combination.

\section{Results and Discussion}

Variation among cultivars in stomatal conductance. Late afternoon $g_{\mathrm{S}}$ was lower than midday $g_{\mathrm{S}}$ across all cultivars, N05 rates, and W05 treatments and the change in $g_{S}$ between midday and late afternoon varied between cultivars (Fig. 1A; within-subject time by cultivar interaction, $P<0.05$ ). There were no significant interactions between time of day that $g_{\mathrm{S}}$ was measured and $\mathrm{N} 05$ rate or time of day and W05 treatment. Therefore, data from the midday and late afternoon $g_{\mathrm{S}}$ were pooled for each measurement date and analyzed using ANOVA in a full factorial design with cultivar, N05 rate, and W05 treatment as between-subject main effects and date (measurement date) as a within-subject repeated measure.

Daily and seasonal variation in $g_{\mathrm{S}}$ differed among cultivars. On average, plants of PJM had the highest $g_{\mathrm{S}}$ and ER had the lowest $g_{\mathrm{S}}$ (Fig. 1B). Plant size may play a role in these $g_{\mathrm{S}}$ differences among cultivars. Larger plants, in general, will have greater demands for water (Augé and Moore, 2002). Plants of ER grew more in 2005 than AZ and PJM (Fig. 4C). For all three cultivars, midday $g_{\mathrm{S}}$ was higher than late afternoon $g_{\mathrm{S}}$, and ER had the largest decrease in $g_{\mathrm{S}}$ between midday and late afternoon.

The $g_{\mathrm{S}}$ from July through September was greater in PJM than ER (Fig. 1B) suggesting PJM were exposed to less water stress than ER during the growing season. Water stress during the growing season can affect the ability of evergreen plants to assimilate carbon in the fall (Vaz et al., 2010). The recovery of $g_{\mathrm{S}}$ in the fall was greater in PJM than ER (Fig. 1B), suggesting that water availability may have decreased late-season carbon assimilation in ER. Others have reported that in the fall, on rewetting, carbon assimilation and $g_{\mathrm{S}}$ in evergreen species can recover from summer water deficits (Vaz et al., 2010). The recovery response of $g_{\mathrm{S}}$ varies with plant species and recovery of $g_{\mathrm{S}}$ in plants exposed to greater water stress during the growing season may be lower. Fall recovery of carbon assimilation and $g_{\mathrm{S}}$ compared with activity in the summer highlights the importance of the evergreen habit for whole plant carbon assimilation after summer drought and, 
therefore, for the accumulation of reserves in roots and stems. Thus, differences in $g_{\mathrm{S}}$ between PJM and ER that may be function of plant size can alter the ability of plants to recover from water stress.

The $g_{\mathrm{S}}$ from July to September was similar in ER and AZ, whereas the $g_{\mathrm{S}}$ in September and October was lower in ER than AZ (Fig. 1B). In contrast, the $g_{\mathrm{S}}$ from July to September was greater in PJM than $\mathrm{AZ}$ and $g_{\mathrm{S}}$ in PJM and $\mathrm{AZ}$ was similar starting in September (Fig. 1B). Differences among cultivars in late-season $g_{\mathrm{S}}$ may be a combined result of plant size, growth habit (e.g., deciduous vs. evergreen), and recovery of $g_{\mathrm{S}}$ after water stress. For example, differences in $g_{\mathrm{S}}$ between ER and $\mathrm{AZ}$ in the fall may reflect variation in growth habit (e.g., deciduous vs. evergreen). Leaf $g_{\mathrm{S}}$ changes with plant age and leaf maturation (Bauerle et al., 2004). Senescing leaves can lose their ability to regulate stomatal cells thereby having greater $g_{\mathrm{S}}$ (Herrick and Thomas, 2003). Leaves of AZ started to change color and abscise in October. Thus, differences in $g_{\mathrm{S}}$ between ER and AZ in the fall may be a function of leaf maturation and not just plant size. In contrast, in the fall when leaves in AZ were losing their ability to regulate their stomatal cells, their $g_{\mathrm{S}}$ was similar to that of PJM. If we had measured carbon assimilation in our study, we would have been able to determine whether 1) greater $g_{\mathrm{S}}$ was associated with lower photosynthesis in AZ compared with ER; and 2) similar $g_{\mathrm{S}}$ was associated with lower photosynthesis in AZ compared with PJM.

Our results indicate that daily plant demand for water was not completely met by our irrigation treatments and suggest ER may have a greater demand for water than $\mathrm{AZ}$ and PJM. Thus, ER may have been subjected to more water stress on a daily and seasonal basis than AZ and PJM.

Seasonal variation in stomatal conductance. The response of $g_{\mathrm{S}}$ to water availability and plant $\mathrm{N}$ status varied among measurement dates. Increasing the frequency of irrigation increased $g_{\mathrm{S}}$ on five of the nine measurement dates (Fig. 2A). Plants grown with $35 \mathrm{mg} \cdot \mathrm{L}^{-1}$ $\mathrm{N}$ had the greatest $g_{\mathrm{S}}$ on four of the nine measurement dates and plants grown with the highest $\mathrm{N}$ rate had the lowest $g_{\mathrm{S}}$ on four of the nine measurement dates (Fig. 2B).

Our results indicate that neither irrigation treatment was able to meet plant water demands by mid- to late August, and plants were exposed to similar levels of water stress during this time regardless of irrigation frequency and $\mathrm{N}$ rate. Additionally, plants had a greater demand for water in September than earlier in the year, possibly because they were larger and may have used available water more rapidly because their root systems had penetrated more of the growing substrate. Thus, plants with a higher $\mathrm{N}$ status would likely need more water because these plants had more leaves (Fig. 5A) and would have had a higher net transpiration rate. Water deficits resulting from irrigation treatments and seasonal climatic changes would occur more quickly for these plants, causing reductions in their $g_{\mathrm{S}}$.
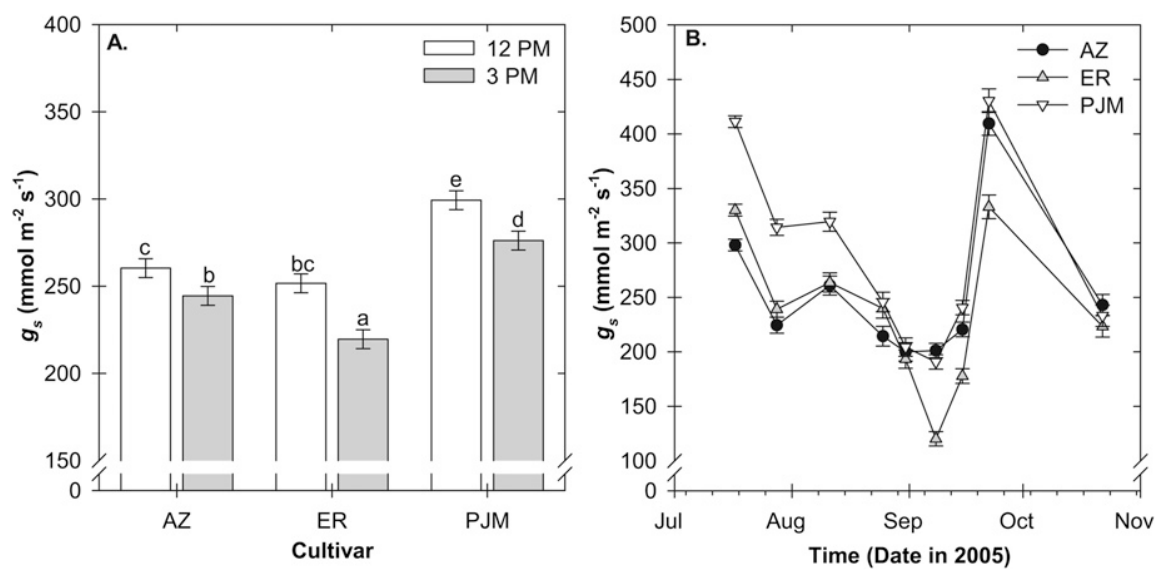

Fig. 1. Stomatal conductance $\left(g_{\mathrm{S}}\right)$ in Rhododendron 'Gibraltar' (AZ), Rhododendron 'English Roseum' (ER), and Rhododendron 'P.J.M.' (PJM) grown in containers. Error bars are least significant differences at $P=0.05$. (A) Mean $g_{\mathrm{S}}$ between 1100 and $1300 \mathrm{HR}$ and 1500 and $1700 \mathrm{HR}$ for each cultivar. Columns denoted by the same lower case letter are not significantly different $(P=0.05)$. (B) Mean $g_{\mathrm{S}}$ for each cultivar on a different measurement date.
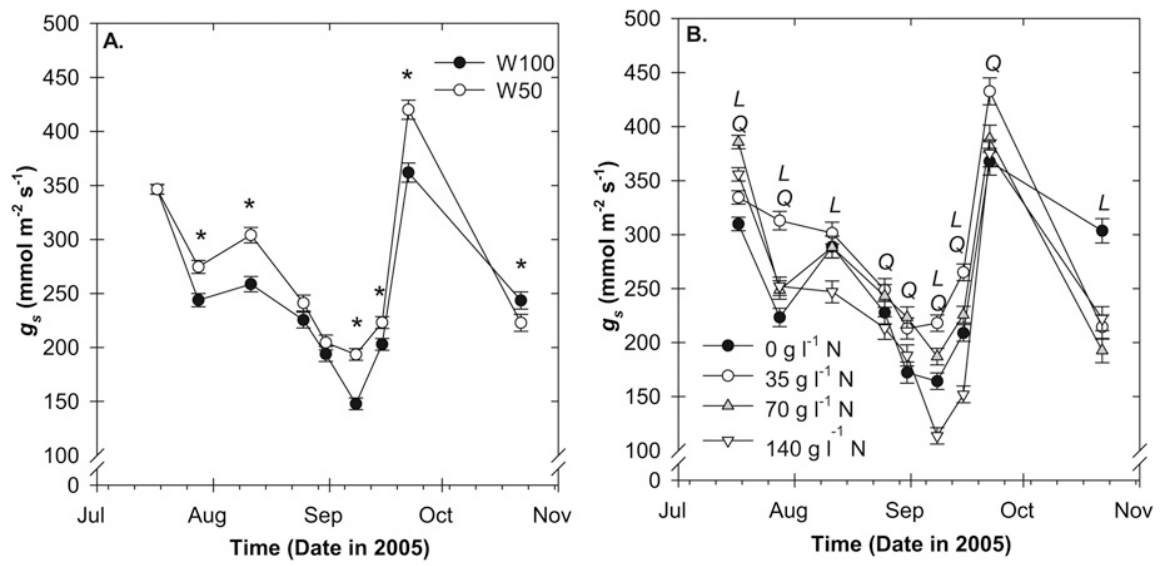

Fig. 2. Stomatal conductance $\left(g_{\mathrm{S}}\right)$ in Rhododendron. Plants were grown in containers with $0 \mathrm{mg} \cdot \mathrm{L}^{-1}, 35$ $\mathrm{mg} \cdot \mathrm{L}^{-1}, 70 \mathrm{mg} \cdot \mathrm{L}^{-1}$, or $140 \mathrm{mg} \cdot \mathrm{L}^{-1}$ nitrogen $(\mathrm{N})$ fertilizer and irrigated once a day $(\mathrm{W} 100)$ or twice a day (W50) to receive the same total daily amount of water between May and Sept. 2005. Error bars are least significant differences at $P=0.05$. Mean $g_{\mathrm{S}}$ for each measurement date and (A) irrigation treatment and (B) N rate. (A) Significant differences $(P=0.05)$ between irrigation treatments denoted by asterisks $(*)$ within date. (B) Significant $(P=0.05)$ linear $(L)$ and quadratic $(Q)$ response of $g_{\mathrm{S}}$ to $\mathrm{N}$ rate within a measurement date indicated above data points.

Effects of nitrogen rate and irrigation frequency on stomatal conductance. Nitrogen application rate altered $g_{\mathrm{S}}$ of container-grown Rhododendron and the response of $g_{\mathrm{S}}$ to water availability imposed by irrigation frequency (Fig. 3). When irrigated once a day, plants grown in the highest $\mathrm{N}$ rate $\left(140 \mathrm{mg} \cdot \mathrm{L}^{-1} \mathrm{~N}\right)$ had the lowest $g_{\mathrm{S}}$. This suggests higher rates of $\mathrm{N}$ application increase plant demand for water and increase the potential for water stress. In contrast, when irrigated more frequently, plants grown with $0 \mathrm{mg} \cdot \mathrm{L}^{-1} \mathrm{~N}$ had similar or lower $g_{\mathrm{S}}$ than plants grown with $140 \mathrm{mg} \cdot \mathrm{L}^{-1} \mathrm{~N}$. When plants were irrigated more frequently, our $g_{\mathrm{S}}$ results support the theory that $\mathrm{N}$ deficient plants generally respond to water shortage by more rapid stomatal closure than plants with higher N status (Marschner, 1995).

More frequent irrigation increased $g_{\mathrm{S}}$ in plants grown with $70 \mathrm{mg} \cdot \mathrm{L}^{-1} \mathrm{~N}$ and $140 \mathrm{mg} \cdot \mathrm{L}^{-1}$ $\mathrm{N}$ and decreased $g_{\mathrm{S}}$ in plants that received $0 \mathrm{mg} \cdot \mathrm{L}^{-1} \mathrm{~N}$ (Fig. 3). Increased irrigation frequency helped to ameliorate water stress related to high $\mathrm{N}$ rates but did not help ameliorate water stress in $\mathrm{N}$-deficient plants. Increasing $\mathrm{N}$ availability generally increases plant growth (Ingestad and Lund, 1986) and increasing plant size increases the amount of water plants required for growth (Augé and Moore, 2002). Nitrogen deficiency may limit a plant's ability to absorb water from the growing substrate, particularly if water distribution within the container is not uniform. Irrigating plants to container capacity once per day may result in a more uniform distribution of water within the growing substrate than more frequent irrigation with the same amount of water.

In general, less frequent irrigation and high $\mathrm{N}$ rates increased water stress in containergrown Rhododendron. The differential influence of $\mathrm{N}$ rate on $g_{\mathrm{S}}$ between the two irrigation frequency treatments is a result of the effects of $\mathrm{N}$ rate on water availability or 
demand (e.g., plant size) and the effects of $\mathrm{N}$ rate on the ability of plants to respond to stress. Plants grown with greater $\mathrm{N}$ rates may be better able to respond to lower levels of water stress (e.g., our W50 treatment) than
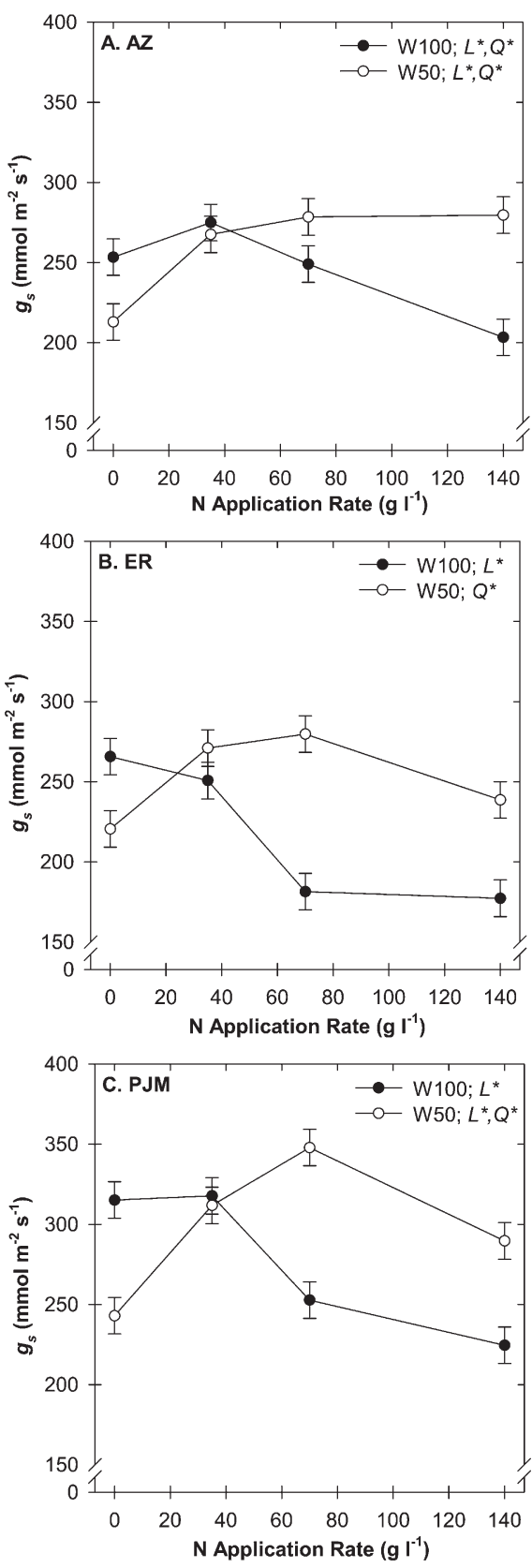

Fig. 3. Stomatal conductance $\left(g_{\mathrm{S}}\right)$ in Rhododendron 'Gibraltar' (AZ), Rhododendron 'English Roseum' (ER), and Rhododendron 'P.J.M.' (PJM). Plants were grown in containers with $0 \mathrm{mg} \cdot \mathrm{L}^{-1}, 35 \mathrm{mg} \cdot \mathrm{L}^{-1}, 70 \mathrm{mg} \cdot \mathrm{L}^{-1}$, or $140 \mathrm{mg} \cdot \mathrm{L}^{-1}$ nitrogen $(\mathrm{N})$ fertilizer and irrigated once a day (W100) or twice a day (W50) to receive the same total daily amount of water between May and Sept. 2005. Error bars are least significant differences at $P=0.05$. Mean $g_{\mathrm{S}}$ for each cultivar within $\mathrm{N}$ rate and irrigation treatment Differences in significant $(P=0.05)$ linear $(L)$ and quadratic $(Q)$ response of $g_{\mathrm{S}}$ to $\mathrm{N}$ rate between irrigation treatments denoted by asterisks $(*)$ in legend. plants grown at lower $\mathrm{N}$ rates. However, at higher levels of water stress (e.g., our W100 treatment), plants grown at the higher $\mathrm{N}$ rates are more sensitive. The level of water stress imposed by our treatments was much lower than the $g_{\mathrm{S}}$ reported when deficit irrigation was used with container-grown Rhododendron (Cameron et al., 1999; Sharp et al., 2008). Deficit irrigation treatments in these studies caused large decreases in $g_{\mathrm{S}}\left(\approx 50 \mathrm{mmol} \cdot \mathrm{m}^{-2} \cdot \mathrm{s}^{-1}\right.$ compared with $\approx 400 \mathrm{mmol} \cdot \mathrm{m}^{-2} \cdot \mathrm{s}^{-1}$ in wellwatered plants). On the dates we measured $g_{\mathrm{S}}$, it was rarely below $\approx 100 \mathrm{mmol} \cdot \mathrm{m}^{-2} \cdot \mathrm{s}^{-1}$ and seldom above $\approx 400 \mathrm{mmol} \cdot \mathrm{m}^{-2} \cdot \mathrm{s}^{-1}$. It is possible stronger linear responses of $g_{\mathrm{S}}$ to $\mathrm{N}$ rate are more common when plants are under greater water stress.

Growth and nitrogen uptake. Plant growth in 2005 increased linearly with increasing rate of $\mathrm{N}$ application. For every gram of $\mathrm{N}$ applied, $\mathrm{AZ}$ accumulated $21 \mathrm{~g}$ to $22 \mathrm{~g}$ biomass, PJM accumulated $29 \mathrm{~g}$ to $32 \mathrm{~g}$ biomass, and ER accumulated $46 \mathrm{~g}$ to $51 \mathrm{~g}$ biomass by Nov. 2005. Increased irrigation frequency (and de-
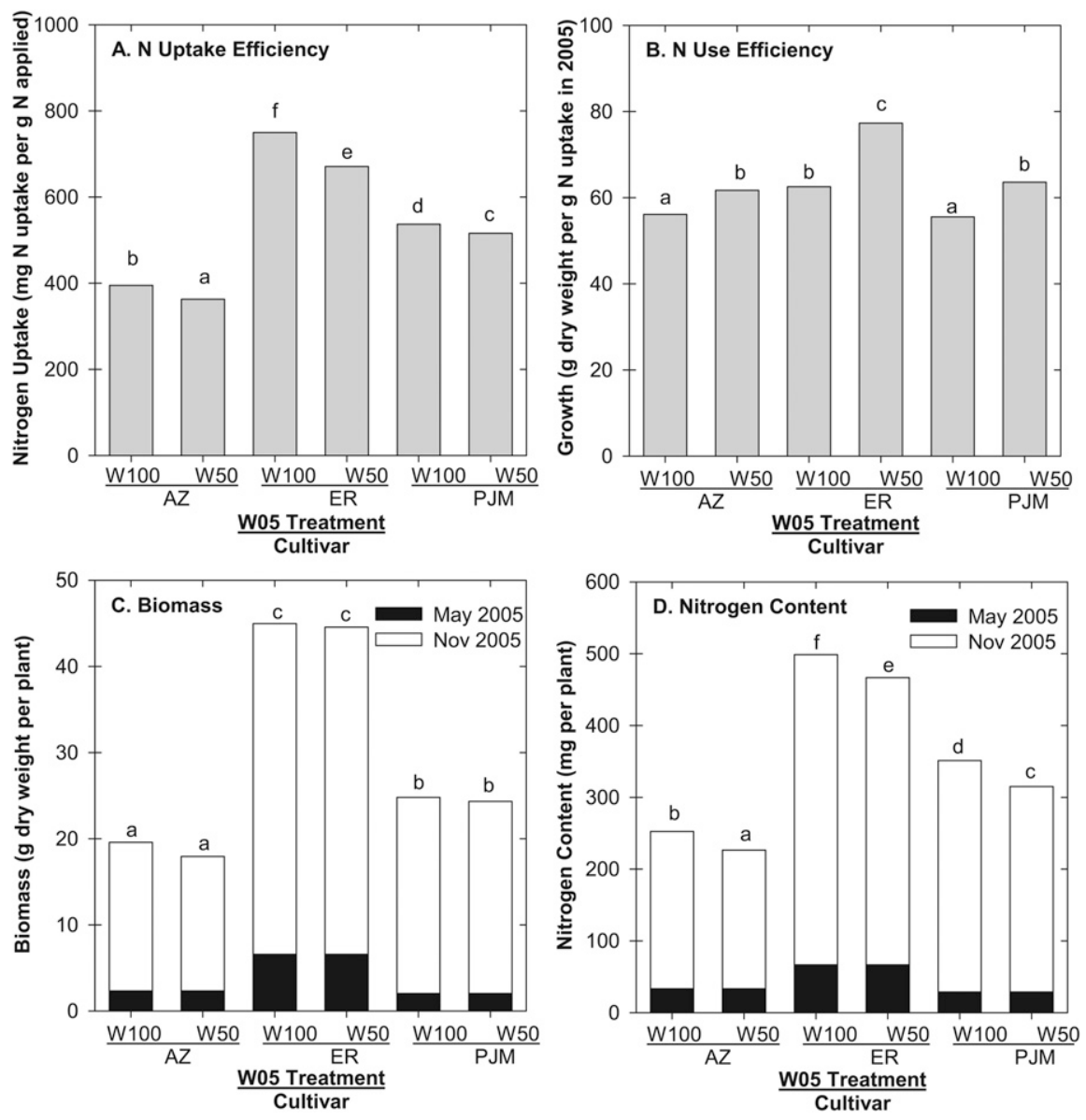

Fig. 4. (A) Nitrogen (N) uptake efficiency, (B) $\mathrm{N}$ use efficiency, (C) biomass, and (D) $\mathrm{N}$ content in Rhododendron 'Gibraltar' (AZ), Rhododendron 'English Roseum' (ER), and Rhododendron 'P.J.M.' (PJM). Plants were grown in containers with $0 \mathrm{mg} \cdot \mathrm{L}^{-1}, 35 \mathrm{mg} \cdot \mathrm{L}^{-1}, 70 \mathrm{mg} \cdot \mathrm{L}^{-1}$, or $140 \mathrm{mg} \cdot{ }^{-1} \mathrm{~N}$ fertilizer and irrigated once a day (W100) or twice a day (W50) to receive the same total daily amount of water between May and Sept. 2005. First-order regression coefficients for relationships between (A) N application rate in 2005 and net N uptake between May 2005 and Nov. 2005 and (B) N uptake in 2005 and growth between May 2005 and Nov. 2005. (C-D) Mean $(n=20)$ biomass and N content in May 2005 (May 2005) and net change in biomass and N content between May 2005 and Nov. 2005 (Nov. 2005). Significant differences $(P<0.05)$ between cultivars and W05 treatments denoted by different lower case letters. 
production of nursery crops can increase $\mathrm{N}$ leaching from containers and potentially decrease $\mathrm{N}$ uptake because $\mathrm{N}$ is lost from the growing substrate and unavailable for plant uptake (Cabrera, 2004; Million et al., 2007). Plants in the W100 treatment received more water at one time than plants in the W50 treatment and $\mathrm{N}$ uptake by W100 plants was greater than W50 plants (Fig. 4). Additionally, during irrigation events, no water was observed leaving the bottom of containers in the W50 treatment. This suggests that the effect of irrigation frequency on $\mathrm{N}$ uptake was not a result of lower $\mathrm{N}$ availability in the W50 plants as a result of leaching but instead the ability of roots to absorb $\mathrm{N}$ was altered by irrigation frequency.

Irrigating plants more frequently may result in higher salt accumulation in containers because of reduced leaching. Compared with overhead irrigation, subirrigation more completely saturates the container substrate and has lower pour-through electrical conductivity (EC) resulting in improved $\mathrm{N}$ uptake ability by azalea at lower $\mathrm{N}$ fertilizer rates (Million et al., 2007). It is possible $\mathrm{N}$ uptake by plants in our W50 treatment was restricted as a result of higher substrate EC, which could also influence uptake of potassium and calcium (Marschner, 1995).

Irrigating plants less frequently and increasing $\mathrm{N}$ fertilizer application rate can increase water stress in container-grown Rhododendron and plants may respond by altering $\mathrm{N}$ accumulation and efficiency of $\mathrm{N}$ use without influencing growth. Plant $\mathrm{N}$ status in the fall is frequently correlated with plant performance during the next growing season (Millard, 1996). Low levels of water stress during container production of Rhododendron may not impact net total carbon gain but has the potential to alter $\mathrm{N}$ uptake and thus influence plant performance during the next growing season.

Biomass allocation. Cultivars preferentially allocated biomass to different structures in the fall (Fig. 5). On average, biomass allocation to roots was highest in AZ and lowest in ER, biomass allocation to stems was highest in PJM and lowest in ER, and biomass allocation to leaves was highest in ER and lowest in AZ. In the fall, deciduous plants generally store reserves in roots and evergreen plants store reserves in different structures depending on the cultivar (Ingestad, 1991; Millard, 1996). Our results suggest AZ preferentially allocated biomass to roots and ER to leaves. Plants of PJM generally store more reserves in roots and stems than ER and ER generally stores more reserves in leaves than PJM (Scagel et al., 2007). The effects of irrigation treatments and $\mathrm{N}$ rate on biomass allocation may be related to where and when cultivars preferentially allocate resources.

Irrigating ER and PJM more frequently decreased biomass allocation to roots and increased biomass allocation to stems of ER and leaves of PJM (Fig. 5B). Increasing rate of N application decreased biomass allocation to roots of all cultivars and increased biomass allocation to aboveground structures (Fig. 5A).
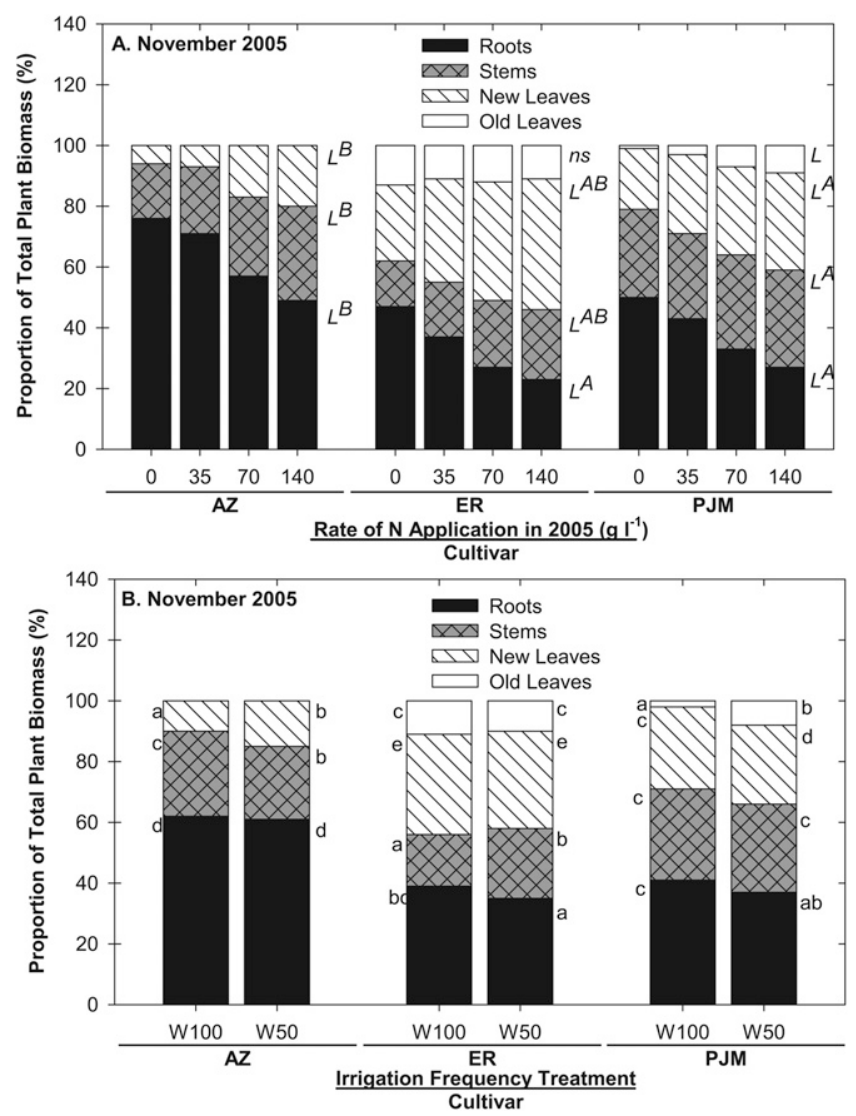

Fig. 5. Biomass allocation in Nov. 2005 in Rhododendron 'Gibraltar' (AZ), Rhododendron 'English Roseum' (ER), and Rhododendron 'P.J.M.' (PJM). Plants were grown in containers with 0 mg. $\mathrm{L}^{-1}, 35$ $\mathrm{mg} \cdot \mathrm{L}^{-1}, 70 \mathrm{mg} \cdot \mathrm{L}^{-1}$, or $140 \mathrm{mg} \cdot \mathrm{L}^{-1}$ nitrogen $(\mathrm{N})$ fertilizer and irrigated once a day $(\mathrm{W} 100)$ or twice a day (W50) to receive the same total daily amount of water between May and Sept. 2005. New stems and new leaves originated in 2005 and old stems and old leaves originated before 2005. Non-significant (ns) and significant $(P<0.05)$ linear $(L)$ relationships between N05 rate and response variable indicated adjacent to structure within a cultivar and differences between cultivars in $L$ response to N05 rate denoted by upper case superscript letters following $L$ within a structure (A). Significant differences $(P<0.05)$ between cultivars and W05 treatments for each response variable denoted by different lower case letters within a structure $(\mathbf{B})$.

Increased allocation of biomass to roots is a common plant response to nutrient and water deficits. Nutrient uptake by roots, even in the constraints of a container, is greater when plants have larger root systems (Agren and Ingestad, 1987; Tan and Hogan, 1997). Drought stress and $\mathrm{N}$ deficiency have similar effects on $g_{\mathrm{S}}$, root/shoot ratios, and abscisic acid levels in plants (Marschner, 1995). All cultivars allocated more biomass to roots in response to $\mathrm{N}$ limitation but only ER and PJM allocated more biomass to roots in response to decreased irrigation frequency. Less frequent irrigation increased water stress and was associated with increased $\mathrm{N}$ uptake and biomass allocation to roots in ER and PJM. This suggests that greater N uptake in W100 ER and PJM may be a result of increased biomass allocation to roots.

More frequent irrigation in $\mathrm{AZ}$ had no influence on biomass allocation to roots, decreased biomass allocation to stems, and increased allocation to leaves (Fig. 5B). Many woody deciduous plants store reserves for the next growing season in roots (Millard, 1996) and nutrient and biomass import to roots of AZ can occur as early as September (Scagel et al., 2007). Water stress can decrease accumulation of reserves and promote early nutrient mobilization to storage (Sanz-Pérez et al., 2009). Leaves in W100 AZ changed color and abscised earlier in the fall than leaves in W50 AZ (data not shown). Water stress may have decreased reserve storage in AZ roots; however, the timing of our harvest in the fall may not reflect these effects as a result of how irrigation treatments influenced the timing of mobilization.

Irrigating plants less frequently can increase water stress of container-grown Rhododendron and plants may respond by altering plant form (biomass allocation) without a detectable change in growth (total plant biomass). Plant form can be as important to nursery stock quality as plant growth (Cameron et al., 2008; Sharp et al., 2008; Tan and Hogan, 1997). Our results indicate water stress from irrigation frequency may not impact total growth but has the potential to alter biomass allocation and thus influence plant form (e.g., leaf retention, stem growth, etc.) and $\mathrm{N}$ uptake and $\mathrm{N}$ use efficiency.

In conclusion, using $g_{\mathrm{S}}$ as an estimate of plant water stress, our results indicate that decreasing the frequency of irrigation increases water stress of container-grown 
Rhododendron and plants grown with high rates of $\mathrm{N}$ fertilizer are more susceptible to water stress, particularly when plant water requirements are highest as a result of growth and environmental conditions. Additionally, relatively small, transitory increases in plant water stress at different times during the growing season can alter $\mathrm{N}$ uptake and plant form without impacting total plant biomass.

\section{Literature Cited}

Ågren, G.I. and T. Ingestad. 1987. Root:shoot ratio as a balance between nitrogen productivity and photosynthesis. Plant Cell Environ. 10:579-586.

Augé, R.M. and J.L. Moore. 2002. Stomatal response to nonhydraulic root-to-shoot communication of partial soil drying in relation to foliar dehydration tolerance. Environ. Exp. Bot. 47:217-229.

Bauerle, W., J.E. Toler, and G.G. Wang. 2004. Stomatal conductance of Acer rubrum ecotypes under varying soil and atmospheric water conditions: Predicting stomatal responses with an abscisic acid-based model. Tree Physiol. 24: 805-811.

Beeson, R.C., Jr. 1992. Restricting overhead irrigation to dawn limits growth in container-grown woody ornamentals. HortScience 27:996-999.

Beeson, R.C., Jr. 2006. Relationship of plant growth and actual evapotranspiration to irrigation frequency based on management allowed deficits for container nursery stock. J. Amer. Soc. Hort. Sci. 131:140-148.

Berg, M.G. and E.H. Gardner. 1979. Methods of soil analysis used in the soil testing laboratory at Oregon State University. Oregon State Univ. Agric. Exp. Stn. Special Report. No. 321

Bi, G., C.F. Scagel, L.H. Fuchigami, and R.P. Regan. 2007a. Differences in growth, and nitrogen uptake and storage between two containergrown cultivars of Rhododendron. J. Environ. Hort. 25:13-20.

Bi, G., C.F. Scagel, L.H. Fuchigami, and R.P. Regan. 2007b. Rate of nitrogen application during the growing season alters the response of container-grown rhododendron and azalea to foliar application of urea in the autumn. J. Hort. Sci. Biotechnol. 82:753-763.

Buljovcic, Z. and C. Engels. 2001. Nitrate uptake ability by maize roots ruing and after drought stress. Plant Soil 229:125-135.

Cabrera, R.I. 2004. Nitrogen balance for two contain-grown woody ornamental plants. Sci. Hort. 97:297-308.

Cameron, R., R. Harrison-Murray, M. Fordham, S. Wildinson, W. Davies, C. Atkinson, and M. Else. 2008. Regulated irrigation of woody ornamentals to improve plant quality and precondition against drought stress. Ann. Appl. Biol. 153:49-61.

Cameron, R.W.F., R.S. Harrison-Murray, and M.A. Scott. 1999. The use of controlled water stress to manipulate growth of container-grown Rhododendron cv Hoppy. J. Hort. Sci. Biotechnol. 74:161-169.

Chapin, F.S., III, E. Schulze, and H.A. Mooney. 1990. The ecology and economics of storage in plants. Annu. Rev. Ecol. Syst. 21:423-447.

Cowan, I.R. 1977. Stomatal behavior and environment. Adv. Bot. Res. 4:117-227.

Fare, D.C., C.H. Gilliam, G.J. Keever, and J.W. Olive. 1994. Cyclic irrigation reduces container leachate nitrate-nitrogen concentration. HortScience 29:1514-1517.

Herrick, J.D. and R.B. Thomas. 2003. Leaf senescence and late-season net photosynthesis of sun and shad leaves of overstory sweetgum ( Liquidambar styraciflua) grown in elevated carbon dioxide concentration. Tree Physiol. 23:108118.

Ingestad, T. 1991. The influence of plant nutrition on biomass allocation. Ecol. Appl. 1:168-174.

Ingestad, T. and A.B. Lund. 1986. Theory and techniques for steady state mineral nutrition and growth of plants. Scand. J. For. Res. 1:439453.

Keever, G.J. and G.S. Cobb. 1985. Irrigation scheduling effects on container media and canopy temperatures and growth of 'Hershey's red' azalea. HortScience 20:921-923.

LI-COR. 1989. LI-1600 Steady state porometer instruction manual. Publ. No. 8210-0030. LICOR, Inc., Lincoln, NE.

Linder, S., M.L. Benson, B.J. Myers, and R.J. Raison. 1987. Canopy dynamics and growth of Pinus radiata. I. Effects of irrigation and fertilization during a drought. Can. J. For. Res. 17:1157-1165.

Marschner, H. 1995. Mineral nutrition of higher plants. 2nd Ed. Academic Press, San Diego, CA.

Millard, P. 1996. Ecophysiology of the internal cycling of nitrogen for tree growth. Z. Pfanzenernär 159:1-10.

Million, J., T. Yeager, and C. Larsen. 2007. Water use and fertilizer response of azalea using several no-leach irrigation methods. HortTechnology 17:21-25.

Paternoster, R., R. Brame, P. Mazerolle, and A. Piquero. 1998. Using the correct statistical test for the quality of regression coefficients. Criminology 38:859-866.

Raviv, M., R. Wallach, A. Silber, S. Medina, and A. Krasnovsky. 1999. The effect of hydraulic characteristics of volcanic materials on yield of roses grown in soilless culture. J. Amer. Soc. Hort. Sci. 124:205-209.

Rose, M.A., M. Rose, and H. Wang. 1999. Fertilizer concentration and moisture tension affect growth and foliar N, P, and $\mathrm{K}$ of two woody ornamentals. HortScience 34:246-250.

Sanz-Pérez, V., P. Castro-Díez, and R. Joffre. 2009. Seasonal carbon storage and growth in Mediterranean tree seedlings under different water conditions. Tree Physiol. 29:11051116.

Scagel, C.F., G. Bi, L.H. Fuchigami, and R.P. Regan. 2007. Seasonal variation in growth, nitrogen uptake and allocation by containergrown evergreen and deciduous Rhododendron cultivars. HortScience 42:1440-1449.

Scagel, C.F., G. Bi, L.H. Fuchigami, and R.P. Regan. 2008. Nitrogen availability alters mineral nutrient uptake and demand in containergrown deciduous and evergreen Rhododendron. J. Environ. Hort. 26:177-187.

Scheiber, S.M., R.C. Beeson, J. Chen, Q. Wang, and B. Pearson. 2008. Evaluation of irrigation frequency and quantity on leaf gas exchange, growth, and nitrate leaching of Coleus in a simulated landscape. HortScience 43:881884.

Sharp, R.G., M.A. Else, R.W. Cameron, and W.J. Davies. 2008. Water deficits promote flowering in Rhododendron via regulation of pre and post initiation development. Sci. Hort. 120: 511-517.

Silber, A., G. Xu, I. Levkovitch, S. Soriano, A. Bilu, and R. Wallach. 2003. High fertigation frequency: The effects on uptake of nutrients, water, and plant growth. Plant Soil 253:467477.

Tan, W. and G.D. Hogan. 1997. Physiological and morphological responses to nitrogen limitation in jack pine seedlings: Potential implications for drought tolerance. New For. 14:19-31.

Vaz, M., J.S. Pereira, L.C. Gazarini, T.S. David, J.S. David, A. Rodrigues, J. Maroco, and M.M. Chaves. 2010. Drought-induced photosynthetic inhibition and autumn recovery in two Mediterranean oak species (Quercus ilex and Quercus suber). Tree Physiol. 30:946-956.

Welsh, D.F. and J.M. Zajicek. 1993. A model for irrigation scheduling in contain-grown nursery crops utilizing management allowed deficits (MAD). J. Environ. Hort. 11:115-118.

Xu, G., I. Levkovitch, S. Soriano, R. Wallach, and A. Silber. 2004. Integrated effect of irrigation frequency and phosphorus level on lettuce: $\mathrm{P}$ uptake, root growth, and yield. Plant Soil 263: 297-309. 